\title{
Identification of Risk Factors Characteristics of Transfusion Reaction
}

\author{
Eko Putri Rahajeng, Raehana Samad, Rachmawati Muhiddin
}

Department of Clinical Pathology, Faculty of Medicine, Hasanuddin University/Dr. Wahidin Sudirohusodo Hospital, Makassar, Indonesia. E-mail: putrirahajeng28@gmail.com

\begin{abstract}
Blood transfusion is an important part of health care. A blood transfusion can be carried out after careful consideration of its risks and benefits. One of the important considerations for blood transfusion is adverse transfusion reaction. Several risk factors for a transfusion reaction are age, gender, repeated transfusion, disease diagnosis, type of blood component, and blood incompatibility. This research is a descriptive study performed at Blood Bank Dr. Wahidin Sudirohusodo Hospital, Makassar, from January to December 2017. The subjects were all patients reported to have an acute transfusion, totaling 104 subjects. The descriptive method was carried out by the calculation of frequency distribution. From January to December 2017 , 104 patients with transfusion reactions were obtained, predominantly were male (53.8\%), with the lowest age range of $\geq 60$ years (27.9\%), packed red cell as the most found blood components (82.4\%), a history of previous transfusion reactions (72.1\%), and a diagnosis of malignancy (53.9\%). The history of repeated transfusions is the most common risk factor compared to age, gender, blood component, and patient diagnosis.
\end{abstract}

Keywords: Transfusion reaction, risk factors

\section{INTRODUCTION}

Blood transfusion is the transfer process of blood or its component from a donor into the recipient's circulatory system. Blood transfusion is an important part of health care, and if used properly, it can save the lives of patients and improve health. Indications of blood transfusion are to increase blood oxygen capacity, restore blood volume to maintain effective tissue perfusion, and to replace platelets, coagulation factors, and other plasma proteins. The proper indication of blood transfusion is to treat conditions that can cause morbidity and mortality that cannot be overcome by other means. ${ }^{1-4}$

A blood transfusion can be carried out after careful consideration of its risks and benefits. One consideration for blood transfusion decisions is the possibility of an adverse transfusion reaction. Transfusion reactions are unwanted effects that occur in patients during or after receiving blood products. Transfusion reactions can be categorized into two types, such as acute transfusion reactions which occur within the first 24 hours after the transfusion, and delayed transfusion reactions which occur within more than 24 hours (several days or months after the transfusion) ${ }^{1.5}$

Based on complaints and signs, transfusion reactions can be divided into three categories: mild, moderate, and severe. Mild transfusion reactions are characterized by the onset of localized pruritus, urticaria, and localized rash. Moderate reactions are characterized by anxiety, pruritus, palpitations, mild shortness of breath, and headaches; while signs and symptoms of severe reactions include anxiety, chest pain, pain in the area of needle injection, respiratory distress, back pain or groin pain, headache, hypotension ( $\geq 20 \%$ decrease of systolic pressure), and tachycardia ( $\geq 20 \%$ increase of heart race). Delayed transfusion reactions include delayed hemolytic reaction, post-transfusion purpura, graft versus host disease, iron overload and transfusion transmissible infections. ${ }^{6,7}$

Some risk factors for transfusion reactions include age, gender, history of repeated transfusions, diagnosis of disease, type of blood component, blood incompatibility. The incidence of transfusion reactions for each individual is different, due to differences in susceptibility and immunological response. ${ }^{8,9}$

Research by Payandeh et al., at the Teaching Hospital of Kermanshah University of Medical Sciences Iran in 2010-2012 found a total of 6,238 units of transfused blood components. Fifty-nine (0.94\%) cases of transfusion reaction were reported in these three years. The most common allergic reactions were urticaria, rash and pruritus (49.2\%), non-hemolytic febrile transfusion reactions (37.2\%) pain in the transfusion area (6.8\%) and hypotension (6.8\%). ${ }^{10}$ 
Research by Lubart et al., at the Geriatric Hospital of Israel, of 382 blood units given to 242 patients during the study period, 40 (11\%) cases of transfusion reaction were found. Fever was the most common transfusion reaction in 29 cases (72\%), shortness of breath was found in $4(10 \%)$ cases, while vomiting and shivering were found in $3(8 \%)$ cases. $^{1,11}$

The mortality rate of transfusion reactions in the United States were approximately 1-1.2 cases $/ 100,000$ patients who received blood transfusions, urticaria was found in 10,000-20,000 cases/1 million of transfused blood, fever was found in 5,000-10,000 cases, while fatal acute hemolytic reactions were found in approximately 1-2 cases/ 1 million transfusions. According to the US Food and Drug Administration (FDA), 30 to 44 patients die from transfusion reactions per year in the United States between 2009 and 2013.,12

There has been an increased number of transfusion reactions in the Blood Bank of Dr. Wahidin Sudirohusodo Hospital in Makassar in the last three years. A transfusion reaction is the potential to delay the patient's treatment related to the underlying disease, increase medical costs, and extend the length time of hospital stay. The occurrence of transfusion reactions is one indicator of quality assessment of hospital services based on KARS and JCI accreditation. Based on the above background, researchers are interested in researching risk factors that influence the incidence of transfusion reactions to improve hospital services, especially in Dr. Wahidin Sudirohusodo Hospital, Makassar. ${ }^{13}$ This study aimed to determine the risk factors which influence the occurrence of transfusion reactions.

\section{METHODS}

This research is a descriptive study carried out by taking secondary data of patients who received blood transfusions and experienced acute transfusion reactions based on SIRS data and reports of transfusion reaction data on Blood Bank Dr. Wahidin Sudirohusodo Hospital, Makassar from a period of January to December 2017. The descriptive method was carried out by the calculation of the frequency distribution.

The study population was all patients reported with transfusion reaction at the Blood Bank Dr. Wahidin Sudirohusodo Hospital. The study subjects were all patients who reported having an acute transfusion reaction at the Blood Bank Dr. Wahidin Sudirohusodo Hospital, Makassar from January to December 2017. Sample inclusion criteria were all patient data with a report of acute transfusion reaction from the period January 2017 - December 2017. Exclusion criteria were incomplete medical record data such as age, gender, blood type, disease diagnosis; a history of the previous transfusion (if any); a history of incompatibility (if any); and type of blood product given.

Research permission was obtained from the Health Research Ethics Committee of the Faculty of Medicine, Hasanuddin University/Central General Hospital Dr. Wahidin Sudirohusodo, Makassar, and Hasanuddin University Hospital Makassar with number 344/H4.8.4.5.31/PP36-KOMETIK/2017.

\section{RESULTS AND DISCUSSIONS}

This study was carried out by taking data of patients who experienced transfusion reaction at the Blood Bank of Dr. Wahidin Sudirohusodo Hospital, Makassar from January to December 2017. A total of 104 subjects were involved.

Most research subjects had O blood type (42.3\%) and most types of reactions were mild (60.6\%). This was in line with the results of other studies that similarly found $O$ blood type as the mostly found blood type in patients with transfusion reactions. Research by Apriastini et al. found that out of 107 study samples with transfusion reactions, 64 samples belong to $O$ blood type. A study by Wiwi et al. suggested that blood type is the main risk factor for acute transfusion reactions, and subjects with blood type $O$ are 2.7 times more likely to experience an acute transfusion reaction than a non- $O$ blood group. The results of this study were also in line with a study by Mehrdad et al. at the Teaching Hospital of Kermanshah University of Medical Sciences in Iran suggesting that the most commonly found reactions were urticaria, rashes and pruritus (49.2\%), non-hemolytic febrile transfusion reactions (37.2\%) pain in the transfusion area (6.8\%) and hypotension (6.8\%), respectively. ${ }^{10,14,15}$

Table 1 shows that the subjects were predominantly males (53.8\%), age of $\geq 60$ years $(50.0 \%)$, malignancy as the mostly found diagnosis (53.8\%). The mostly found blood component was PRC (82.4\%), and most subjects had a history of blood transfusion (82.4\%).

The higher percentage of males with transfusion reactions compared to females in this study was in line with research by Apriastini et al., which found 65 males of a total of 107 subjects. A similar result was obtained in the study by Samsiar et al., which found 138 (51.5\%) males from 268 subjects. ${ }^{14,16}$ However, the results in this study were not in line with the 
Table 1. Distribution of subjects characteristics

\begin{tabular}{lccc}
\hline \multicolumn{1}{c}{ Variable } & Category & $\mathbf{n}$ & $\%$ \\
\hline Total subject $(\mathrm{n}=104)$ & Male & 56 & 53.8 \\
Gender & Female & 48 & 46.2 \\
& $<12$ years old & 8 & 7.7 \\
Age & $12-25$ years old & 17 & 16.4 \\
& $26-45$ years old & 25 & 24.0 \\
& $46-59$ years old & 25 & 24.0 \\
History of transfusion & $\geq 60$ years old & 29 & 27.9 \\
& Yes & 75 & 72.1 \\
Blood component & No & 29 & 27.9 \\
& Packed Red Cell (PRC) & 84 & 82.4 \\
& Thrombocyte Concentrate (TC) & 14 & 13.7 \\
& Thrombopheresis & 3 & 2.9 \\
Diagnosis & Whole Blood (WB) & 1 & 1.0 \\
& Malignancy & 56 & 53.8 \\
& Trauma & 13 & 12.5 \\
& Kidney, heart, lung & 7 & 6.7 \\
& Gastroenterohepatology & 8 & 7.7 \\
& others & 20 & 19.3 \\
\hline
\end{tabular}

Source: Secondary data

Table 2. Distribution of gender, age, and diagnosis based on the history of blood transfusion

\begin{tabular}{lcccccc} 
& & \multicolumn{4}{c}{ History of Blood Transfusion } \\
\cline { 3 - 6 } & & \multicolumn{3}{c}{ Yes } & \multicolumn{3}{c}{ No } \\
\cline { 3 - 6 } & & $\mathrm{n}$ & $\%$ & $\mathrm{n}$ & $\%$ \\
\hline \multirow{2}{*}{ Gender } & Male & 41 & 73.2 & 15 & 26.8 \\
& Female & 34 & 70.8 & 14 & 29.2 \\
& < 12 years old & 7 & 87.5 & 1 & 12.5 \\
& $12-25$ years old & 10 & 58.8 & 7 & 41.2 \\
& 26-45 years old & 18 & 75.0 & 7 & 25.0 \\
& 46-59 years old & 17 & 68.0 & 8 & 32.0 \\
Diagnosis & 260 years old & 22 & 75.7 & 7 & 24.1 \\
& Malignancy & 45 & 80.4 & 11 & 19.6 \\
& Trauma & 7 & 53.8 & 4 & 38.4 \\
& Kidney, heart, lung & 2 & 28.6 & 5 & 71.4 \\
& gastroenterohepatology & 5 & 62.5 & 3 & 37.5 \\
& Others & 14 & 70.0 & 6 & 30.0 \\
\hline
\end{tabular}

Source: Secondary data

results of several studies, such as one by Chakravarty-Vartak et al., which found $75 \%$ female patients and six pregnant female, where in five multigravida female were identified. Similar results were also obtained by Ibrahim et al., showing $86 \%$ multigravida female of total subjects studied in cases of acute transfusion reactions in pregnancy. In pregnant female alloantibodies can be formed against leukocytes, erythrocytes, or platelets that occur due to fetomaternal hemorrhage. Female who develop leukocyte antibodies after pregnancy are more likely to experience non-hemolytic febrile transfusion reactions if transfused with blood containing leukocyte components. ${ }^{5,17}$

The higher percentage of transfusion reactions in male compared to female subjects in this study was presumably due to the high population of male subjects who received transfusions during the 
current time. Based on data from Blood Bank of Dr. Wahidin Sudirohusodo Hospital, Makassar, from January to December 2017 there were $60 \%$ of total 8.405 patients who received blood transfusions from males. Also, Table 2 shows that $73.2 \%$ of the total of 56 male subjects experienced transfusion reactions (history of previous transfusions). This caused a higher number of male subjects with a transfusion reaction.

In this study $27.9 \%$ of samples aged $\geq 60$ years, the age with the most case of transfusion reactions. This is due to the decrease of the body's immune system, with increasing age the body's immune ability against infection decreases including the speed of the immune response. Table 2 shows that of the 29 samples aged $\geq 60$ years, and 22 samples that had a history of transfusion. It also supports the number of transfusion reactions that occur in this study aged $\geq 60$ years. $^{18}$

History of transfusion is an important factor which influences the occurrence of transfusion reactions. In this study, there were $(72.1 \%)$ subjects who experienced a transfusion reaction had a history of previous transfusions. This was in line with research by Apriastini et al., which found that 72 of the 107 subjects with a transfusion reaction had a history of previous transfusions. Individuals who have a history of repeated transfusions will experience sensitization which leads to the formation of alloantibodies in the recipient's body due to exposure to Human Leukocyte Antigen (HLA) or Human Platelet Antigen (HPA) through previous transfusions. Interactions between donor antigens and recipient antibodies that have undergone prior sensitization trigger systemic inflammation with cytokine release (IL-1, TNF). ${ }^{7.14}$

All types of blood components have the potential to cause transfusion reactions, especially blood components which contain leukocytes. The TC component contains $<0.5 \mathrm{~mL}$ erythrocytes/unit and $5 \times 106$ leukocytes. In addition to leukocytes, it contains, the TC component has the highest risk of bacterial contamination (1:2000) because it is stored at room temperature, compared to the lower risk of contamination (1:500 000) in the administration of PRC concentrates. In this study, there were (82.4\%) subjects who experienced a transfusion reaction and received a transfusion of the PRC blood component. This is because the PRC component is the transfusion with the highest demand in the Blood Bank of Dr. Wahidin Sudirohusodo Hospital. Contrastingly, only $1 \%$ of WB transfusion was found in this study due to a lack of demand. ${ }^{14,19}$ In this study the most common diagnosis was malignancy (53.8\%). Any disease group with a diagnosis of malignancy belongs to hematologic malignancies. Blood transfusion is a potential source of transmission of viruses, bacteria, and parasites. The severity of the reaction to bacterial contamination in blood components depends on the immune status of the patient. Patients with a diagnosis of malignancy are in a state of compromised immunity, resulting in a decrease in the body's response to eliminate T lymphocytes from donor blood components. Disease groups that fall into the other categories include infections, post-partum gravida, electrical burn injury. ${ }^{20}$

The crossmatch test is an in-vitro cross-reaction between the blood of the patient and the donor before blood transfusion. This reaction is intended to determine the presence or absence of irregular antibodies in the serum of patients and donors. Based on the results of the pre-transfusion crossmatch test in patients with transfusion reactions, 101 (97.1\%) compatible results, and 3 (2.9\%) minor incompatible results. Furthermore, there were $65(62.6 \%)$ compatible results at pre- and post- transfusion (Table 3).

This shows that before transfusion there is in-vitro compatibility between antibody-antigen from the donor and the recipient and vice versa. Transfusion reactions with compatible results at crossmatch tests show that the transfusion reactions

Table 3. The characteristics of transfusion reaction based on crossmatch test results

\begin{tabular}{|c|c|c|c|c|c|c|c|c|c|}
\hline & & \multicolumn{6}{|c|}{ Post-Transfusion } & \multirow{2}{*}{\multicolumn{2}{|c|}{ Total }} \\
\hline & & \multicolumn{2}{|c|}{ Compatible } & \multicolumn{2}{|c|}{$\begin{array}{c}\text { Minor } \\
\text { incompatibility }\end{array}$} & \multicolumn{2}{|c|}{ Not tested } & & \\
\hline & & $\mathrm{n}$ & $\%$ & $\mathrm{n}$ & $\%$ & $\mathrm{n}$ & $\%$ & $\mathrm{n}$ & $\%$ \\
\hline \multirow[t]{2}{*}{ Pre-transfusion } & Compatible & 65 & 62.6 & 9 & 8.7 & 27 & 25.9 & 101 & 97.1 \\
\hline & $\begin{array}{l}\text { Incompatible } \\
\text { minor }\end{array}$ & - & - & 2 & 1.9 & 1 & 0.9 & 3 & 2.9 \\
\hline Total & & 65 & 62.5 & 11 & 10.6 & 28 & 26.9 & 104 & 100.0 \\
\hline
\end{tabular}

Source: Secondary data 
which occur are not caused by mismatches between donor antibodies and patients, but possibly due to hypersensitivity reactions caused by proteins in both plasma of patients and donors. Hypersensitivity reactions are mediated by IgE which reacts with allergens (plasma proteins) leading to mast cell activation. ${ }^{21}$

There were 27 (25.9\%) samples that were compatible with pre-transfusion becoming incompatible minor post-transfusion. This can be caused by the presence of irregular antibodies found in donors or recipients. This is often associated with human errors such as sample labeling errors, patient identification errors, interpretation errors, an error of recording crossmatch test results at the pre-transfusion stage. ${ }^{7}$

Another thing which is able to affect the transfusion reactions is the length of the storage of blood components. An increase in the amount of cytokines can be found in the stored blood components, which can cause a transfusion reaction. The longer time of storage led to the higher the risk of reaction. This was in accordance with research by Ibrahim et al., suggesting that there was a very significant difference between $>24$ hour-stored blood and $<24$ hour-non stored blood to the occurrence of transfusion reactions. These events can also be caused by bacterial contamination of blood components. Contamination can occur in the process of donor blood collection, blood processing, damaged blood bags, and in the process of blood storage. ${ }^{3,7,17}$

\section{CONCLUSIONS AND SUGGESTIONS}

The results in this study suggested that there were many risk factors which were able to cause transfusion reactions. The history of transfusion was the most influential factor in the occurrence of transfusion reactions in patients. It was recommended to perform blood transfusion with the proper indication of transfusion to overcome conditions causing morbidity and mortality which is unable to be overcome by other means. It was recommended further research by analyzing the relationship of transfusion reactions with factors which influence the occurrence of transfusion reactions.

\section{REFERENCES}

1. Dalimoenthe NZ. Persiapan transfusi dalam dasar-dasar transfusi darah. Ed kedua., Divisi Hematologi Klinik Departemen Patologi Klinik,
Bandung, Fakultas Kedokteran Universitas Padjajaran, 2014; 84-100.

2. Sood AK. Health benefit of blood donation. Available from: http://bloodbankbdcnsr.org/sood.pdf. Accessed on 15 February 2018.

3. WHO. The clinical use of blood: Handbook. Geneva, Available http://www.who.int/bloodsafety/ clinical_use/en/Handbook_EN.pdf. Accessed 15 February 2018.

4. Kiechl S, Willeit J. Ongoing controversies surrounding the vascular benefits of blood donation. Journal of the American Heart Association, 2001; 104-9.

5. Chakravarty U, Shewale R, Vartak S, Faizal F, Majethia N. Adverse reactions of blood transfusion: A study in a tertiary care hospital. International Journal of Scientific Study. Available from: http://www.ijss-sn. com/uploads/2/0/1/5/20153321/ijss_may_oa19.pdf. Accessed 15 February 2018.

6. Peraturan Menteri Kesahatan Republik Indonesia no 91 tahun 2015 tentang standar pelayanan transfusi darah. Jakarta, 2015; 253-4.

7. Adewoyin AS, Oyewale OA. Complications of allogeneic blood transfusion: Current approach to diagnosis and management. International Blood Research \& Reviews, 2015; 135-151. Accessed 15 February 2018.

8. Nix MP, Zundel WB, Harmening DM. Modern blood banking and transfusion practices. $5^{\text {th }}$ Ed., Pretransfusion Compatibility Testing, 2005; 264-82.

9. Abbas AK, Lichtman HK, Pillai S. Cellular and molecular immunology. $8^{\text {th }}$ Ed., Immunologic Tolerance and Autoimmunity, 2015; 315-38.

10. Mehrdad P, Erfan ZM. Description of acute transfusion reactions in the Teaching Hospitals of Kermanshah University of Medical Sciences, Iran. International Journal of Hematology-Oncology and Stem Cell Research, Available from: https://www.ncbi.nlm.nih. gov/pmc/articles/PMC3913142/. Accessed 15 February 2018.

11. Lubart E, Segal R, Tryhub N, Sigler E, Leibovitz A. Blood transfusion reactions in elderly patients hospitalized in a multilevel geriatric hospital. Available from: https://www.hindawi.com/journals/jar/2014/178298/ Accessed 15 February 2018.

12. Dasararaju R, Marques MB. Adverse effects of transfusion. Cancer Control, 2015; 22(1): 16-25. Accessed 15 February 2018.

13. Mulyantari NK, Subawa AAN, Yasa Sutirta P. Tranfusion reactions as an indicator service quality of blood transfusion in Sanglah General Hospital Denpasar Bali-Indonesia. Udayana University. Bali. Available from: https://ojs.unud.ac.id/index.php/ bmj/article/view/2394. Accessed 8 April 2018.

14. Apriastini NKT, Ariawati K. Risk factors of acute blood transfusion reactions in pediatric patients in Sanglah General Hospital. Bali. Available from https://www.balimedicaljournal.org/index.php/bmj/a rticle/viewFile/630/953 Accessed 15 April 2018.

15. Payung W, Rachmawati AM, Arif M. Factors in acute transfusion reaction. Indonesian Journal of Clinical 
Pathology and Medical Laboratory, 2018; 22(3): 274-278.

16. Samsiarah $\mathrm{H}$, Dachlan I. A comparison study on the blood transfusion reaction between the elective and the emergency operation's patients. Available from: https://jurnal.ugm.ac.id/bik/search/titles, Accessed 15 February 2018.

17. Ibrahim UN, Garba N, Tilde ID. Acute blood transfusion reactions in pregnancy, an observational study from North Eastern Nigeria. Journal of Blood Disorders \& Tranfusion. Available from: https://Www.Omicsonline.Org/ Acute-Blood-Transfusion-Reactions-In-Pregnancy-An-Obse. Accessed 15 February 2018.

18. Fatmah. Respons imunitas yang rendah pada tubuh manusia usia lanjut. 2006 Available from: http://journal.ui.ac.id/index.php/health/article/viewFi le/169/165. Accessed 15 February 2018.

19. Clevenger B, Kelleher A. Hazards of blood transfusion in adults and children. 2013. Available from : https://academic.oup.com/bjaed/article/.../ Hazards-of-blood-transfusion-in-adults-and. Accessed 15 March 2018.

20. Dubey A. Issues pertaining to blood transfusion in immunocompromised patients. J Immun Res, 2015; 2(2): 1019. Accessed 15 Maret 2018.

21. Squires JE. Risks of transfusion. South Med J, 2011; 104(11): 762-9. Accessed 15 March 2018. 